\title{
Kinetics and Equilibrium Studies for the Removal of Mn and Fe from Binary Metal Solution Systems Using a Romanian Thermally Activated Natural Zeolite
}

\author{
Emilia Neag ${ }^{1}$, Anamaria Iulia Török ${ }^{1}$, Claudiu Tanaselia ${ }^{1}$, Ioan Aschilean ${ }^{2,3}$ and \\ Marin Senila $1, *$ (D) \\ 1 INCDO-INOE 2000, Research Institute for Analytical Instrumentation, 67 Donath st., 400293 Cluj-Napoca, \\ Romania; emilia.neag@icia.ro (E.N.); iulia.torok@icia.ro (A.I.T.); claudiu.tanaselia@icia.ro (C.T.) \\ 2 ZEOLITES PRODUCTION S.A., 1A Samuil Micu st., 400014 Cluj-Napoca, Romania; \\ aschileanioan@gmail.com \\ 3 Faculty of Civil Engineering, Technical University of Cluj-Napoca, 400020 Cluj-Napoca, Romania \\ * Correspondence: marin.senila@icia.ro; Tel.: +40-264-420-590
}

Received: 13 May 2020; Accepted: 2 June 2020; Published: 5 June 2020

check for updates

\begin{abstract}
In the present study, the sorption behavior of iron (Fe) and manganese (Mn) from a binary metal solution system onto thermally activated natural zeolite was studied. Batch adsorption experiments were carried out to investigate the effects of zeolite quantity, particle size, and activation temperature. Equilibrium studies were carried out to evaluate the adsorption capacity of the thermally activated natural zeolite. The obtained results showed that the thermally activated natural zeolite favored the removal of Fe over Mn, due to competition between them. Elemental analysis of the activated zeolite samples obtained by energy-dispersive X-ray analysis (EDX) indicated a Si/Al ratio $>4$, which is specific for clinoptilolite-type zeolite. The removal of Fe and Mn was best described by the Langmuir model, indicating the formation of a monolayer on the surface of the activated natural zeolite. The kinetic results revealed that the experimental data were best fitted by the pseudo-second-order model for both metals. The results suggest that a new natural zeolite from Rupea quarry, Brașov County, Romania could be used as a potential adsorbent for removal of Fe and Mn from binary metal solution systems, addressing the lack of information about this material from this region.
\end{abstract}

Keywords: zeolite; manganese; iron; removal efficiency; isotherm models

\section{Introduction}

Adsorbent materials play a key role in the development of wastewater treatment systems. In recent years, there has been a pronounced tendency to utilize cost-efficient, sustainable, and green adsorbents in the removal of heavy metals for wastewater treatments $[1,2]$.

Zeolites are aluminosilicate minerals characterized by three-dimensional frameworks consisting of tetrahedral $\mathrm{SiO}_{4}$ and $\mathrm{AlO}_{4}$, connected by oxygen atoms. Each substitution of $\mathrm{SiO}_{4}$ by $\mathrm{AlO}_{4}$, generates a negative charge on the framework, which is stabilized by positively charged ions (cations) such as $\mathrm{Na}^{+}, \mathrm{K}^{+}, \mathrm{Ca}^{2+}$, and $\mathrm{Mg}^{2+}[3,4]$.

Natural and modified zeolites have been used successfully in a wide range of applications as low-cost adsorbents [5-9]. However, the adsorption capacity of natural zeolites can be limited by their impurities. To overcome this issue, mechanical, thermal, or chemical treatments can be applied to eliminate the impurities, in order to improve the physicochemical properties and adsorption capacity for heavy metal removal $[10,11]$. Thermal activation is a simple and green method that can generate 
cracks and fragmentation of zeolite, which can improve its adsorption capacity and specific surface area. Thermal activation can also be used to test the material's resistance [12].

The adsorbents used for wastewater treatment should provide specific properties, such as high efficiency, ion-exchange ability, high sorption capacity, high surface area, mechanical strength resistance, and thermal stability [13].

Based on their structural, physical, and chemical properties and local availability in Romania, natural zeolites can be considered highly effective adsorbent materials for use in wastewater filters. Large high-grade zeolite deposits are located in the Transylvanian Basin and in the Precarpathian zone, Romania [14].

Groundwater is an important resource for drinking water, industry, and agriculture (irrigation), and its chemical character is influenced by the physiochemical properties of the minerals that interact with it [15]. Studies have shown that wells contain very high concentrations of iron (Fe) and manganese $(\mathrm{Mn})$ ions [16]. The presence of Fe and Mn in drinking water can cause serious health problems due to (1) the sedimentation of Fe/Mn precipitates in pipeline distribution systems; (2) discolored water when higher discharges occur, due to Fe/Mn precipitates formed in the pipeline distribution systems; (3) metallic taste and odor [17]. Thus, it is necessary to find and to promote easily accessible (local available materials), low-cost, and highly efficient adsorbent materials for Fe and Mn removal [18]. The potential use of adsorbent materials in filters designed for groundwater and wastewater treatment must be highlighted and explained in detail.

According to Romanian legislation, the maximum concentrations of Fe and Mn allowable in drinking water are $0.2 \mathrm{mg} / \mathrm{L}$ and $0.05 \mathrm{mg} / \mathrm{L}$, respectively [19]. The contamination of water by Fe and Mn due to agricultural, industrial, and other anthropogenic activities continues to be a great concern all over the world. The concentrations of Fe and Mn in water must be maintained below acceptable concentrations to ensure the water's quality, including physicochemical parameters and appropriate levels of metals. Therefore, the interaction and behavior of adsorbent materials (zeolite) in the sorption processes of simultaneous Fe and Mn removal from groundwater should be investigated in order to gain a better understanding of the sorption mechanism.

In the present study, a Romanian natural zeolite was thermally activated in order to evaluate its adsorption properties for Fe and Mn removal from a binary metal solution system. The main objectives of the present study were (1) to enhance the adsorption capacity of a natural zeolite for Fe and Mn removal by heat treatment; (2) to investigate the adsorption behavior of a thermally activated natural zeolite for simultaneous removal of Fe and Mn from synthetic aqueous solutions; (3) to obtain detailed information on the equilibrium and kinetic removal properties of Fe and Mn using thermally activated natural zeolite; and (4) to characterize the natural zeolite activated by heat treatment.

\section{Materials and Methods}

\subsection{Thermal Activation of Natural Zeolite}

Natural zeolite obtained from Rupea Quarry, Brașov County, Romania was crushed and sieved in order to obtain various particle sizes of $<0.5 \mathrm{~mm}, 0.5-1.25 \mathrm{~mm}$, and $2-3 \mathrm{~mm}$. Prior to the activation treatment, the adsorbent was washed with distilled water to remove the impurities from its surface and dried in an oven at $105{ }^{\circ} \mathrm{C}$ for $24 \mathrm{~h}$. The natural zeolite was thermally activated at $200{ }^{\circ} \mathrm{C}$ for $2 \mathrm{~h}$ as the first stage ( $\mathrm{NZ} \Rightarrow \mathrm{NZ} 200$ ). NZ 200 was then subjected to a new activation treatment at temperatures of $250{ }^{\circ} \mathrm{C}$ (NZA 250) or $550{ }^{\circ} \mathrm{C}$ (NZA 550) for $1 \mathrm{~h}$ as the second stage. Thus, in the second stage, the activation of NZA 250 and NZA 550 was as follows: NZ $\Rightarrow$ NZ $200 \Rightarrow$ NZA 250 and $\mathrm{NZ} \Rightarrow \mathrm{NZ} 200 \Rightarrow$ NZA 550, respectively. Subsequently, the effectiveness of the adsorbent materials obtained from the first (NZ 200) and second stages (NZA 250 and NZA 550) for simultaneous removal of Fe and Mn was evaluated. 


\subsection{Batch Sorption Experiments}

Two stock solutions of $1 \mathrm{~g} / \mathrm{L} \mathrm{FeSO}_{4}$ and $1 \mathrm{~g} / \mathrm{L} \mathrm{MnSO}_{4}$ were prepared by dissolving the salts in distilled water. The desired concentrations were prepared by diluting the concentrated stock solutions. All the reagents were of analytical purity and were purchased from Merck, Darmstadt, Germany.

The experiments were performed in batch mode, contacting different quantities of NZ 200 (0.5-4 g) with $100 \mathrm{~mL}$ at different $\mathrm{Fe}$ and $\mathrm{Mn}$ initial concentrations at a stirring rate of $100 \mathrm{rpm}$. All the experiments were performed at room temperature $\left(23 \pm 2{ }^{\circ} \mathrm{C}\right)$. Samples were taken at established time intervals and were filtered before chemical analysis. All the experiments were conducted in triplicate and the average values were used.

The Fe and Mn concentrations were determined using an inductively coupled plasma optical emission spectrometer (ICP-OES), Optima 5300 DV (Perkin-Elmer, Ontario, Canada). The Fe and Mn amount in the adsorbent phase, $q_{e}(\mathrm{mg} / \mathrm{g})$, was calculated using Equation (1), while removal efficiency, $E(\%)$, was calculated using Equation (2).

$$
\begin{gathered}
q_{e}=\frac{\left(C_{o}-C_{e}\right)}{m} \cdot \frac{V}{1000} \\
E(\%)=\frac{\left(C_{o}-C_{e}\right)}{C_{o}} \cdot 100
\end{gathered}
$$

where $q_{e}$ is the Fe and Mn amount adsorbed per gram of adsorbent at equilibrium $(\mathrm{mg} / \mathrm{g}), V$ is the volume of solution (mL), $m$ is the weight of activated zeolite $(\mathrm{g}), C_{e}$ is the equilibrium Fe and $\mathrm{Mn}$ concentration $(\mathrm{mg} / \mathrm{L})$, and $C_{o}$ is the initial Fe and Mn concentration $(\mathrm{mg} / \mathrm{L})$ [20].

\subsection{Characterization of the Activated Zeolite Samples}

The morphology of NZ 200 with a smaller particle size $(<0.5 \mathrm{~mm})$ was examined using a SU-8230 ultra-high-resolution scanning electron microscope (SEM) (Hitachi, Tokyo, Japan).

The energy-dispersive X-ray (EDX) analysis of the NZ 200, NZA 250, and NZA 550 samples with smaller particle sizes $(<0.5 \mathrm{~mm})$ was also observed using this instrument, coupled with an X-Max 1160 EDX detector (Oxford Instruments, Oxford, UK).

To determine $\mathrm{pH}$, an amount of $10 \mathrm{~g}$ of zeolite was contacted with $50 \mathrm{~mL}$ water and stirred for $1 \mathrm{~h}$. The $\mathrm{pH}$ of the solution was determined using a Seven Excellence multiparameter (Mettler Toledo, Greifensee, Switzerland) after $1 \mathrm{~h}$ of settling.

The point of zero charge $\left(\mathrm{pH}_{\mathrm{pzc}}\right)$ of the zeolite samples $(0.5 \mathrm{~g})$ was determined using $0.01 \mathrm{M} \mathrm{NaCl}$ solution $(50 \mathrm{~mL})$ at $\mathrm{pH} 2-12$. The initial $\mathrm{pH}\left(\mathrm{pH}_{\mathrm{i}}\right)$ of the $\mathrm{NaCl}$ solution was adjusted with $0.1 \mathrm{~mol} / \mathrm{L}$ $\mathrm{HCl}$ or $0.1 \mathrm{~mol} / \mathrm{L} \mathrm{NaOH}$. The final $\mathrm{pH}\left(\mathrm{pH}_{\mathrm{f}}\right)$ of the solutions was measured after $48 \mathrm{~h}$ of contact. $\mathrm{pH}_{\mathrm{f}}-\mathrm{pH}_{\mathrm{i}}$ was plotted against the $\mathrm{pH}_{\mathrm{i}}$, and the point where $\mathrm{pH}_{\mathrm{f}}-\mathrm{pH}_{\mathrm{i}}=0$ was taken as the $\mathrm{pH}_{\mathrm{pzc}}$ [21]. At a $\mathrm{pH}<\mathrm{pH}_{\mathrm{pzc}}$, the surface charge of adsorbent is positive, attracting anions. When the solution $\mathrm{pH}>\mathrm{pH}_{\mathrm{pzc}}$, the surface charge of the adsorbent is negative and favors cation adsorption [21].

The apparent density was determined by placing the zeolite samples into a $1 \mathrm{~L}$ graduated cylinder. The volume was recorded and the apparent density was calculated using the following equation [22].

$$
\rho=\frac{m}{V_{S}}
$$

where $\rho$ is the apparent density $\left(\mathrm{kg} / \mathrm{m}^{3}\right), m$ is the mass of the sample $(\mathrm{kg})$, and $V_{s}$ is the volume of the sample. 


\section{Theoretical}

\subsection{Adsorption Isotherms}

The Langmuir, Freundlich, and Dubinin-Radushkevich isotherms were considered to describe the simultaneous removal of Fe and Mn from a binary metal solution system.

The equation of the Langmuir isotherm, which suggests a monolayer adsorption onto a surface [23], is given below.

$$
\frac{1}{q_{e}}=\frac{1}{q_{\max } K_{L} C_{e}}+\frac{1}{q_{\max }}
$$

where $K_{L}$ is the Langmuir constant $(\mathrm{L} / \mathrm{mg})$ and $q_{\text {max }}$ is the maximum amount of Fe and Mn adsorbed per gram of adsorbent at equilibrium $(\mathrm{mg} / \mathrm{g})$ [20].

The Langmuir isotherm can be expressed by the equilibrium parameter $R_{L}$ [24].

$$
R_{L}=\frac{1}{1+K_{L} C_{o}}
$$

The $R_{L}$ value indicates the type of the isotherm: unfavorable if $R_{L}>1$, linear if $R_{L}=1$, and favorable if $0<R_{L}<1[6,24]$.

The equation of the Freundlich isotherm, which suggests that the adsorption occurs onto a heterogeneous surface [25], is as follows.

$$
\log q_{e}=\log K_{F}+\frac{1}{n} \log C_{e}
$$

where $K_{F}$ and $n$ are the isotherm constants that indicate the capacity and intensity of the adsorption, and $1 / n$ is a function of the strength of adsorption [20].

If $n$ value lies between 1 and 10, this indicates a favorable adsorption process [20].

The Dubinin-Radushkevich model was applied to express the nature of the adsorption process as physical or chemical [26,27]. Its equations are given as follows.

$$
\begin{gathered}
\ln q_{\mathrm{e}}=\ln q_{\max }-\beta \varepsilon^{2} \\
\varepsilon=R T \ln \left(1+\frac{1}{C_{e}}\right) \\
E_{L}=\frac{1}{\sqrt{-2 \beta}}
\end{gathered}
$$

where $\beta$ is the Dubinin-Radushkevich model constant $\left(\mathrm{mol}^{2} / \mathrm{kJ}^{2}\right), R$ is the gas constant $(8.314 \mathrm{~J} \mathrm{~mol} / \mathrm{K})$, $T$ is the absolute temperature $(\mathrm{K})$, and $E_{L}$ is the mean free energy $(\mathrm{kJ} / \mathrm{mol})[28]$.

The $E_{L}$ value indicates the type of adsorption: physical if $E_{L}<8 \mathrm{~kJ} / \mathrm{mol}$ and chemical if $8<R_{L}<16$ [27].

\subsection{Kinetic Modeling}

In order to describe the kinetics of the Fe and Mn removal from a binary metal solution system by the natural activated zeolite, pseudo-first-order and pseudo-second-order models were applied.

The pseudo-first-order kinetic model equation can be expressed as follows.

$$
\ln \left(q_{e}-q_{t}\right)=\ln q_{e}-k_{1} t
$$

where $q_{t}$ is the Fe and Mn amount adsorbed at time $t$, and $k_{1}$ is the first-order rate constant [29]. 
The pseudo-second-order equation can be expressed as

$$
\frac{\mathrm{t}}{q_{t}}=\frac{1}{k_{2} q_{e}^{2}}+\frac{1}{q_{e}} t
$$

where $k_{2}$ is the second-order rate constant $[29,30]$.

\section{Results and Discussions}

\subsection{Zeolite Characterization}

Scanning Electron Microscopy (SEM) images of the NZ 200 sample with smaller particle sizes $(<0.5 \mathrm{~mm})$ are shown in Figure 1. The rough surfaces were favorable for the adsorption of Fe and Mn.

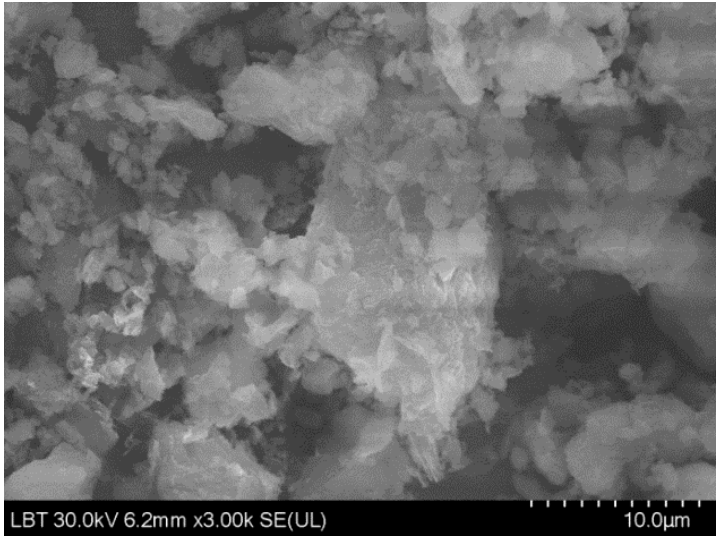

(a)

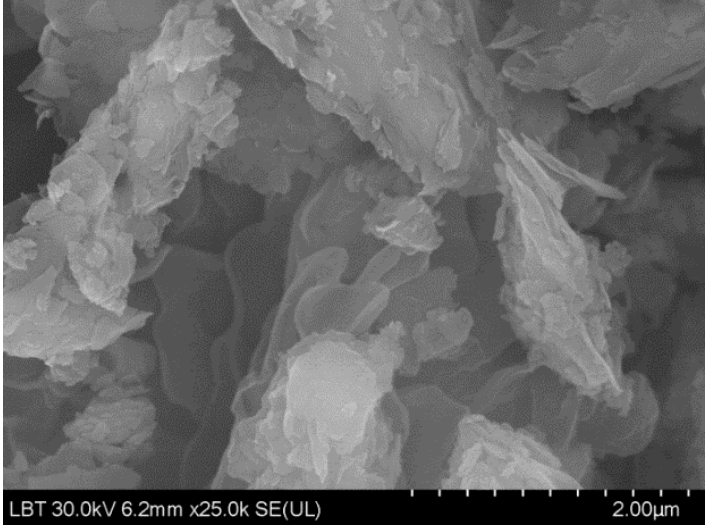

(b)

Figure 1. SEM images of the NZ 200 with a smaller particle size $(<0.5 \mathrm{~mm})$, at two different resolutions: $10 \mu \mathrm{m}(\mathbf{a})$ and $2 \mu \mathrm{m}(\mathbf{b})$.

Elemental analysis of the NZ 200, NZA 250, and NZA 550 samples with smaller particle sizes $(<0.5 \mathrm{~mm})$ obtained via energy-dispersive X-ray analysis (EDX) (Table 1) indicated a Si/Al mass ratio $>4$ and amounts, in grams, of $\mathrm{Na}+\mathrm{K}>\mathrm{Ca}$, which is specific to clinoptilolite-type zeolite [31]. The contents of major elements did not significantly change across the three activation temperatures. Only at the activation temperature of $550{ }^{\circ} \mathrm{C}$, the most major elements show increased concentrations, probably due to the loss of organic carbon from the sample.

Table 1. The composition of thermally activated zeolite samples with smaller particle sizes $(<0.5 \mathrm{~mm})$ expressed as weight (wt. \%).

\begin{tabular}{cccc}
\hline Chemical Elements & NZ 200 (wt. \%) & NZA 250 (wt. \%) & NZA 550 (wt. \%) \\
\hline O & 60.4 & 61.2 & 63.9 \\
$\mathbf{S i}$ & 24.4 & 24.0 & 24.9 \\
$\mathbf{A l}$ & 5.2 & 5.1 & 5.4 \\
$\mathbf{C a}$ & 2.0 & 1.8 & 1.8 \\
$\mathbf{K}$ & 2.1 & 2.2 & 2.3 \\
$\mathbf{F e}$ & 0.9 & 0.8 & 0.6 \\
$\mathbf{M g}$ & 0.8 & 0.7 & 0.6 \\
$\mathbf{N a}$ & 0.5 & 0.6 & 0.5 \\
Others & 3.7 & 3.6 & n.d. \\
\hline
\end{tabular}

n.d.-not detected. 
The physical characteristics of the zeolite samples are given in Table 2. The $\mathrm{pH}$ value of NZ 200 slightly increased (8.95-9.39) as the particle size increased. In contrast, the $\mathrm{pH}$ values for NZA 250 and NZA 550 decreased as the particle size increased. The obtained values suggest that the exchange of $\mathrm{Na}^{+}$(NZ 200, NZA 250, and NZA 550) against $\mathrm{H}^{+}\left(\mathrm{H}_{2} \mathrm{O}\right)$ occurred. The apparent density increased as the particle size of NZ 200, NZA 250, and NZA 550 increased.

Table 2. Physical characteristics of NZ 200, NZA 250, and NZA 550 with different particle sizes.

\begin{tabular}{|c|c|c|c|c|}
\hline \multirow[b]{2}{*}{ Adsorbent } & \multicolumn{4}{|c|}{ Characteristics } \\
\hline & Particle Size (mm) & $\mathrm{pH}$ & Apparent Density $\left(\mathrm{kg} / \mathrm{m}^{3}\right)$ & $\mathrm{pH}_{\mathrm{pzc}}$ \\
\hline \multirow{3}{*}{ NZ 200} & $<0.5$ & 8.95 & 676 & 8.9 \\
\hline & $0.5-1.25$ & 9.21 & 862 & 8.4 \\
\hline & $2-3$ & 9.39 & 893 & 8.1 \\
\hline \multirow{3}{*}{ NZA 250} & $<0.5$ & 8.55 & 676 & 8.7 \\
\hline & $0.5-1.25$ & 7.97 & 909 & 6.9 \\
\hline & $2-3$ & 7.71 & 926 & 6.8 \\
\hline \multirow{3}{*}{ NZA 550} & $<0.5$ & 7.93 & 674 & 8.7 \\
\hline & $0.5-1.25$ & 7.90 & 877 & 8.4 \\
\hline & $2-3$ & 7.58 & 909 & 8.1 \\
\hline
\end{tabular}

The $\mathrm{pH}_{\mathrm{pzc}}$ of NZ 200, NZA 250, and NZA 550 with various particle sizes was determined. The $\mathrm{pH}_{\mathrm{pzc}}$ values for NZ 200, NZA 250, and NZA 550 are given in Table 2. It was found that the $\mathrm{pH}_{\mathrm{pzc}}$ of NZ 200 (8.9-8.1), NZA 250 (8.7-6.8), and NZA 550 (8.7-8.1) decreased as the particle sizes of the zeolite samples increased. Thus, NZ 200 with smaller particle sizes (first stage of activation) exhibited higher $\mathrm{pH}_{\mathrm{pzc}}$ values than NZA 250 and NZA 550 (second stage of activation). The results suggest that the zeolite surface was positively charged when the solution $\mathrm{pH}$ was less than $\mathrm{pH}_{\mathrm{pzc}}$ and negatively charged when the solution $\mathrm{pH}$ was greater than $\mathrm{pH}_{\mathrm{pzc}}$. Thus, when the solution $\mathrm{pH}<\mathrm{pH}_{\mathrm{pzc}}$, anion adsorption was preferred and when the solution $\mathrm{pH}>\mathrm{pH}_{\mathrm{pzc}}$, cation adsorption was favored. Jmayai et al. [32] reported $\mathrm{pH}_{\mathrm{pzc}}$ values between 7.4 and 9.1 for three natural Yemeni zeolites with major minerals such as clinoptilolite and mordenite. Abatal et al. [29] studied the $\mathrm{pH}_{\mathrm{pzc}}$ after acid-modified clinoptilolite-rich tuffs and stated that the adsorbent surface had fewer negative charge sites. Thus, the number of cations decreased and very strong Lewis-acid sites on the surface of the acid-modified clinoptilolite-rich tuffs were formed [29].

\subsection{Sorption Behaviors of Metals in a Binary Metal Solution System}

\subsubsection{Influence of Thermally Treated NZ 200 Quantity}

The experiments were carried out using different NZ 200 quantities with smaller particle sizes $(<0.5 \mathrm{~mm})$, which were contacted with $100 \mathrm{~mL} \mathrm{Fe}$ and Mn solution $(45 / 25 \mathrm{mg} / \mathrm{L} \mathrm{Fe} / \mathrm{Mn})$ at room temperature $\left(23 \pm 2{ }^{\circ} \mathrm{C}\right)$ for $1440 \mathrm{~min}$. Taken into account the fact that the concentration of Fe and $\mathrm{Mn}$ in wastewater varies, NZ 200 quantities in the range of 0.5-4 g were considered. All the experiments were carried out at the same stirring rate of $100 \mathrm{rpm}$. The simultaneous removal of Fe and $\mathrm{Mn}$ by different NZ 200 quantities is presented in Figure 2. 


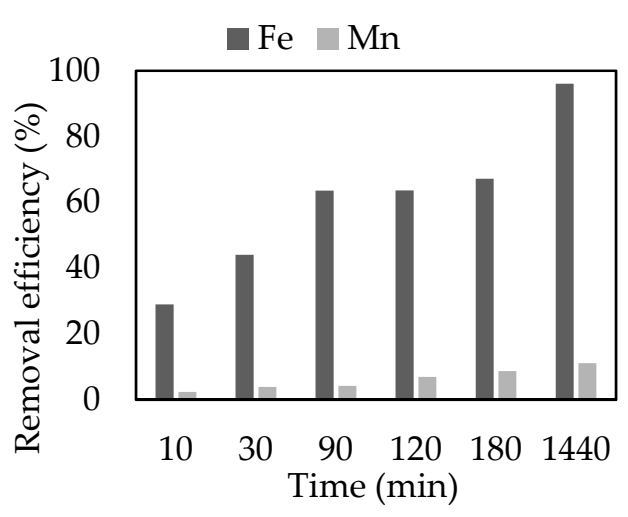

(a)

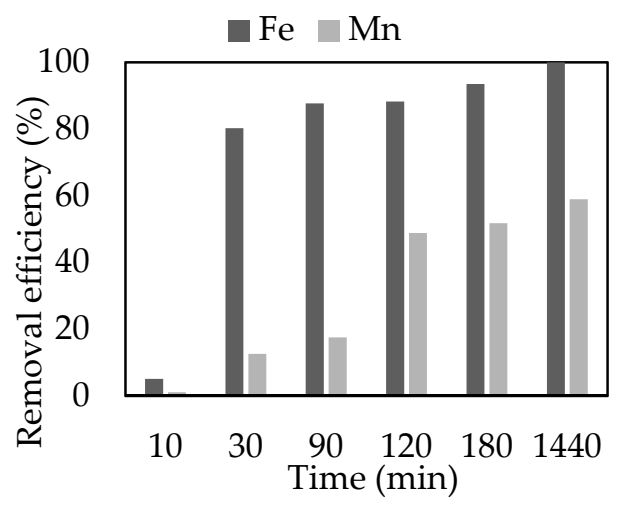

(c)

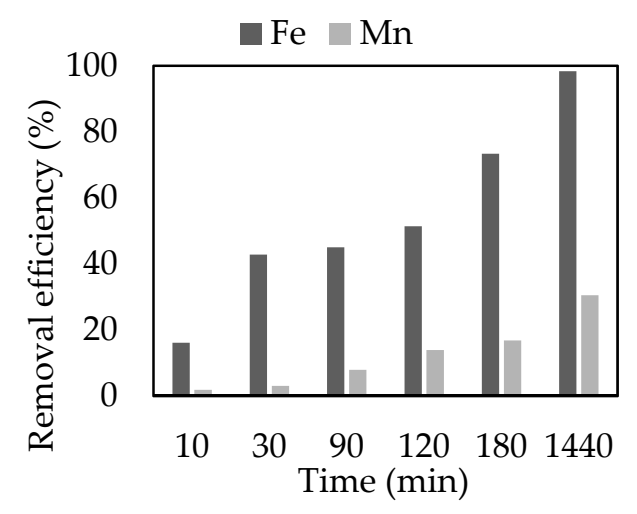

(b)

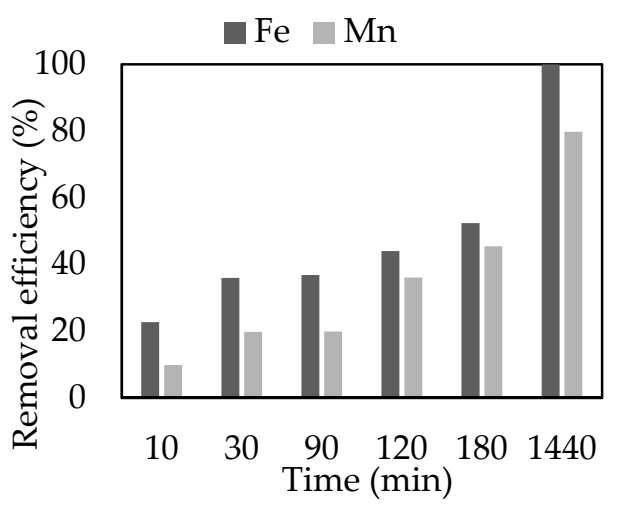

(d)

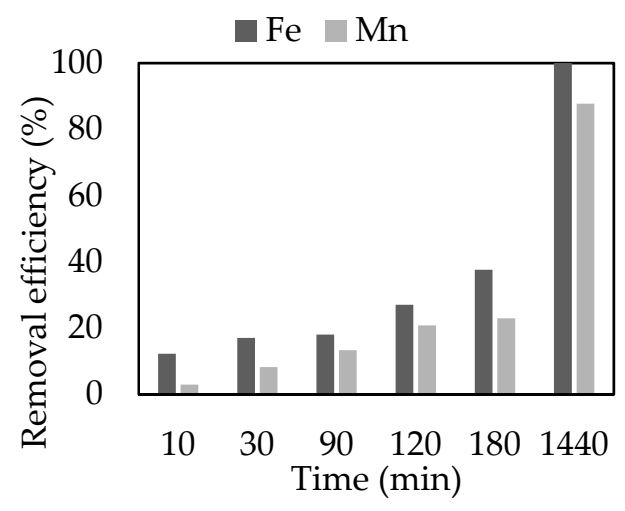

(e)

Figure 2. Simultaneous removal of Fe and Mn by different quantities of NZ 200: $0.5 \mathrm{~g}(\mathbf{a}), 1 \mathrm{~g}(\mathbf{b}), 2 \mathrm{~g}(\mathbf{c})$, $3 \mathrm{~g}(\mathbf{d}), 4 \mathrm{~g}(\mathbf{e}) ; \mathrm{C}_{o}=45 / 25 \mathrm{mg} / \mathrm{L} \mathrm{Fe} / \mathrm{Mn} ; V=100 \mathrm{~mL} ; 100 \mathrm{rpm} ; 23 \pm 2{ }^{\circ} \mathrm{C}$.

In the case of $\mathrm{Fe}$, the results indicated that the removal efficiency rapidly increased as the NZ 200 quantity increased from 0.5 to $2 \mathrm{~g}$ (Figure 2a-e). For Mn, the results showed that the removal efficiency slowly increased up to $180 \mathrm{~min}$. Removal efficiency of $96.1 \%$ at $0.5 \mathrm{~g}$ (Figure 2a), $98.3 \%$ at $1 \mathrm{~g}$ (Figure 2b), and $99.9 \%$ at $2 \mathrm{~g}$ (Figure 2c), $3 \mathrm{~g}$ (Figure 2d), and $4 \mathrm{~g}$ (Figure 2e) were obtained for Fe sorption onto NZ 200 after $1440 \mathrm{~min}$ of contact. However, in the case of Mn, the removal efficiency was low compared with that of Fe: $16.6 \%$ at $0.5 \mathrm{~g}$ (Figure $2 \mathrm{a}$ ), $30.5 \%$ at $1 \mathrm{~g}$ (Figure $2 \mathrm{~b}$ ), $59.0 \%$ at $2 \mathrm{~g}$ (Figure $2 \mathrm{c}$ ), $79.7 \%$ at $3 \mathrm{~g}$ (Figure $2 \mathrm{~d}$ ), and $87.8 \%$ at $4 \mathrm{~g}$ (Figure $2 \mathrm{e}$ ). For both metals, the percentage of the removal efficiency increased after $1440 \mathrm{~min}$ as the NZ 200 quantity increased. The increase in the 
removal efficiency with the increase of zeolite quantity can be associated with the increased number of sites and exchangeable ions available for adsorption [11].

The Fe removal rate was higher than that of $\mathrm{Mn}$ in the binary metal solution system. In particular, it has been reported that the Fe removal on clinoptilolite was higher than that of $\mathrm{Mn}$ in single solution, but in a binary metal solution system both $\mathrm{Fe}$ and $\mathrm{Mn}$ removal rates decreased due to the competition between them for the zeolite active sites $[6,33,34]$. A quantity of $2 \mathrm{~g}$ was chosen for the following experiments. In order to determine whether the first stage of activation is sufficient to increase the sorption capacity of the zeolite, the NZ 200 was further activated at higher temperatures (NZA 250, NZA 550, second stage of activation).

\subsubsection{Influence of Particle Size}

In order to study the effect of particle size of NZ 200, NZA 250, and NZA 550 for Fe and Mn removal, experiments were carried out using a fixed zeolite quantity $(2 \mathrm{~g})$. The initial concentration $(15 / 5 \mathrm{mg} / \mathrm{L} \mathrm{Fe} / \mathrm{Mn})$ and stirring rate $(100 \mathrm{rpm})$ were maintained constant. The performances of the NZ 200, NZA 250, and NZA 550 with different particle sizes for the simultaneous removal of Fe and Mn are presented in Figure 3.

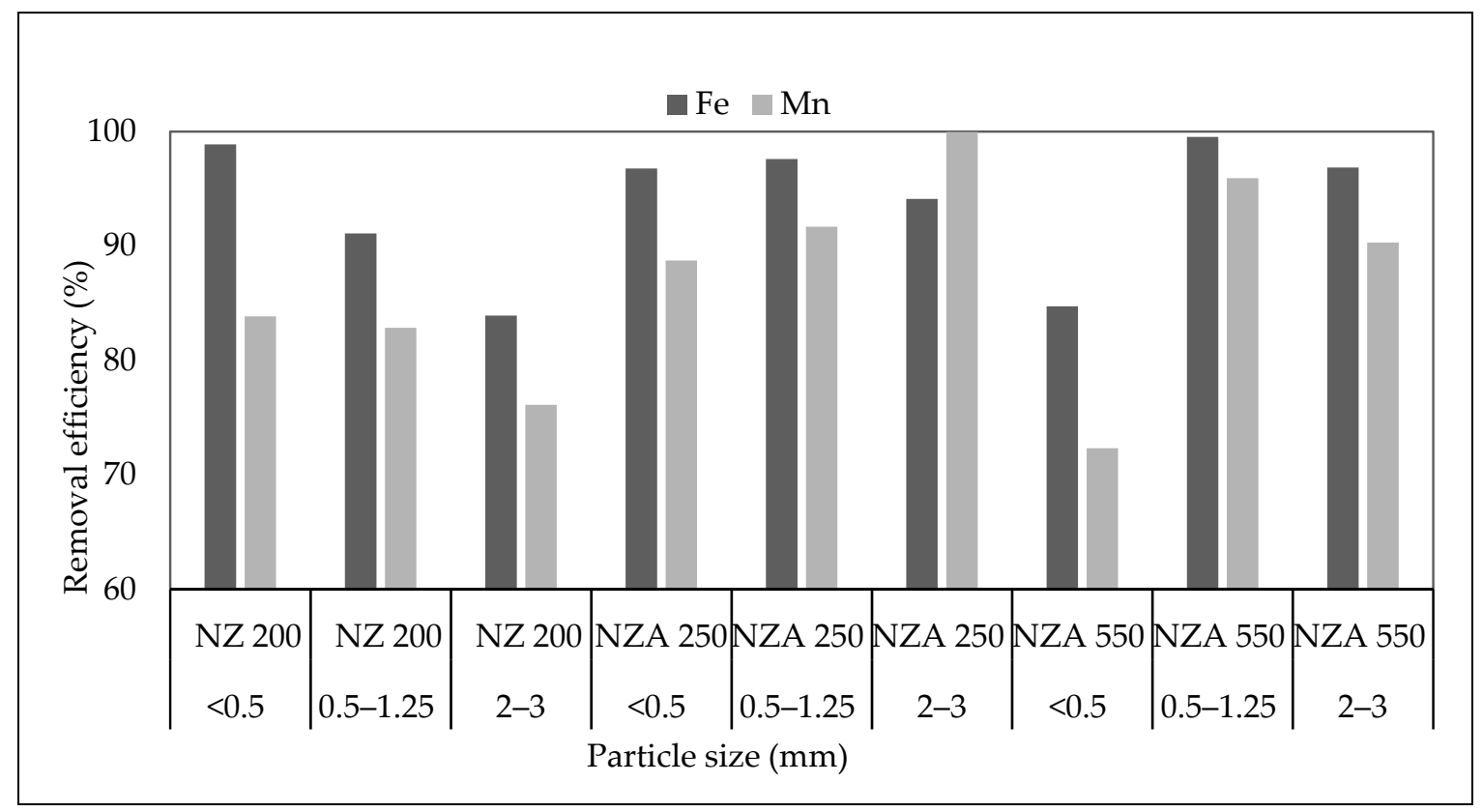

Figure 3. Simultaneous removal of Fe and Mn by NZ 200, NZA 250, and NZA 550 with different particle sizes and activation temperatures; $C_{o}=15 / 5 \mathrm{mg} / \mathrm{L} \mathrm{Fe} / \mathrm{Mn} ; V=100 \mathrm{~mL} ; 2 \mathrm{~g}$ of zeolite; $100 \mathrm{rpm}$.

The obtained results indicated a rapid sorption (after $1 \mathrm{~h}$ ) with removal efficiencies between $83.9 \%$ and $98.9 \%$ for $\mathrm{Fe}$, and 76.1 and $83.9 \%$ for Mn for NZ 200. The maximum Fe and Mn removal was obtained with the NZ 200 of $<0.5$ particle size. It was observed that as the particle size of NZ 200 decreased, the removal efficiency of Fe and Mn slightly increased. A similar trend was observed for removal of $\mathrm{Cd}^{2+}, \mathrm{Cu}^{2+}, \mathrm{Pb}^{2+}$, and $\mathrm{Zn}^{2+}$ using a natural Jordanian of 90-350 $\mu \mathrm{m}$, due to the active surface area of the adsorbent and solid-solution interaction [35]. Moazeni et al. [36] also reported in 2020 that the sorption of $\mathrm{Pb}^{2+}$ increased with decreasing particle size of Iranian natural zeolite (clinoptilolite). Thus, higher adsorption rates under equilibrium conditions can be obtained due to the fact that smaller particles have a larger surface area [36].

Removal efficiencies in the range of $94-98 \%$ for Fe and $89-100 \%$ for Mn were obtained for NZA 250. The obtained results showed a high removal efficiency for Mn using the second-stage thermally 
activated NZA 250, compared with NZ 200 (first-stage) (Figure 3). NZA 250 with a having particle size $>0.5 \mathrm{~mm}$ also revealed higher removal efficiency for Fe removal than NZ with $0.5-2.5 \mathrm{~mm}$ or 2-3 mm.

The removal efficiency of Fe and Mn by NZA 550 was in the range of $85-100 \%$ and $72-100 \%$, respectively. The maximum simultaneous removal efficiency for Fe and Mn was obtained using NZA 550 of $0.5-1.25$ particle size, and the minimum removal efficiency using NZA 550 of $<0.5$ particle size. However, the final concentration for $\mathrm{Mn}$ was above the maximum allowable level in Romanian legislation. The removal of Fe was high compared to $\mathrm{Mn}$, as $\mathrm{Mn}$ is a metal that is not easily removed due to its high hydrated ion radius [34].

\subsubsection{Influence of Activation Temperature on Zeolite Performance}

The experiments were carried out using a fixed zeolite quantity $(2 \mathrm{~g})$ activated at different temperatures. The initial concentration $(15 / 5 \mathrm{mg} / \mathrm{L} \mathrm{Fe} / \mathrm{Mn})$ and stirring rate $(100 \mathrm{rpm})$ were maintained constant. The results are presented in Figure 3.

It was observed that, at the same particle size $(<0.5 \mathrm{~mm})$, the performance of NZA 550 for Mn and Fe removal was lower than that of NZ 200 and NZA 250. The highest Fe and Mn removal efficiency was achieved using thermally activated NZA 550 (0.5-1.25 mm particle size), while the lowest efficiency was obtained using NZ $200(0.5-1.25 \mathrm{~mm})$.

It can be concluded that the optimal thermal activation temperature is $250{ }^{\circ} \mathrm{C}$ (at the second stage of activation), where the removal efficiency was remarkably high for Fe and Mn. Thus, activation of zeolite at temperatures more than $250{ }^{\circ} \mathrm{C}$ is not feasible from an economic point of view. High temperatures favor the destruction of the micropore walls and consequently increase the mesopore content [37].

As it can be seen in Table 3, several studies for Fe and Mn removal from single solutions have been reported in the literature. However, few studies have reported the simultaneous removal of Fe and Mn using zeolites. Garcia-Mendieta et al. [6] reported that in a binary metal solution system, the amount of $\mathrm{Fe}$ and $\mathrm{Mn}$ found in the zeolitic tuff was lower (38.8\% and $12.9 \%$, respectively) than in a single system.

Table 3. Comparison of removal efficiency for several zeolites.

\begin{tabular}{|c|c|c|c|c|c|c|}
\hline & \multirow[t]{2}{*}{ Adsorbent } & \multicolumn{2}{|c|}{ Initial Concentration $(\mathrm{mg} / \mathrm{L})$} & \multicolumn{2}{|c|}{ Removal Efficiency (\%) } & \multirow[t]{2}{*}{ Reference } \\
\hline & & $\mathrm{Fe}$ & Mn & $\mathrm{Fe}$ & Mn & \\
\hline \multirow{3}{*}{ Single solution } & Controll M.F. 574 & 0.322 & 0.123 & 74 & 66 & [38] \\
\hline & Vermiculite & 1.5 & 0.5 & $88-94$ & $65-100$ & [34] \\
\hline & Clinoptilolite & 1.5 & 0.5 & $22-90$ & $61-100$ & [34] \\
\hline \multirow{4}{*}{ Binary metal solution } & Mexican zeolitic tuff & - & - & 38.8 & 12.9 & [6] \\
\hline & NZ 200 & 15 & 5 & $84-98$ & $76-84$ & Present study \\
\hline & NZA 250 & 15 & 5 & $94-98$ & $89-100$ & \\
\hline & NZA 550 & 15 & 5 & $85-100$ & $72-96$ & \\
\hline
\end{tabular}

\subsection{Isotherm Modeling}

The equilibrium data for Fe and Mn removal from a binary metal solution system using different quantities of NZ 200 were modeled using the Langmuir, Freundlich, and Dubinin-Radushkevich isotherm models. The isotherm models express the relationship between the amount of solute adsorbed and its concentration in solution under equilibrium conditions [39].

As shown in Table 4, high $\mathrm{R}^{2}$ values were obtained by fitting the experimental data using the Langmuir, Freundlich, and Dubinin-Radushkevich isotherm models. The sorption constants and correlation coefficients $\left(R^{2}\right)$ for both Langmuir and Freundlich isotherm models are given in Table 4 . The values of maximum adsorption capacity $\left(q_{\max }\right)$ for Fe and Mn obtained using the Langmuir equation were 6.13 and $0.86 \mathrm{mg} / \mathrm{g}$, respectively. The calculated $R_{L}$ values at different NZ 200 quantities for Fe (0.001) and Mn (0.07) removal on NZ 200 indicated a favorable sorption. 
Table 4. Langmuir, Freundlich, and Dubinin-Radushkevich isotherm parameters for Fe and Mn removal using NZ 200 at different adsorbent quantities.

\begin{tabular}{ccccc}
\hline Model & Parameters & Units & Fe & Mn \\
\hline Langmuir & $q_{\max }$ & $\mathrm{mg} / \mathrm{g}$ & 6.13 & 0.86 \\
& $K_{L}$ & $\mathrm{~L} / \mathrm{mg}$ & 17.92 & 0.56 \\
& $R^{2}$ & - & 0.9768 & 0.9726 \\
& $R_{L}$ & - & 0.001 & 0.07 \\
\hline Freundlich & $n$ & - & 2.86 & 5.19 \\
& $K_{F}$ & $\mathrm{~L} / \mathrm{mg}$ & 6.04 & 2.20 \\
& $R^{2}$ & - & 0.9450 & 0.9188 \\
\hline \multirow{2}{*}{ Dubinin-Radushkevich } & $\beta$ & $\mathrm{mol}^{2} / \mathrm{kJ}^{2}$ & $2 \cdot 10^{-9}$ & $2 \cdot 10^{-9}$ \\
& $E_{L}$ & $\mathrm{~kJ} / \mathrm{mol}^{2}$ & 15.81 & 15.81 \\
& $R^{2}$ & - & 0.9445 & 0.929 \\
\hline
\end{tabular}

The $k_{F}$ and $n$ parameters obtained from the Freundlich equation for Fe and Mn removal using NZ 200 are given in Table 4 . The obtained $n$ values suggest a favorable sorption of Fe and Mn on thermally activated NZ 200. It was observed that based on the $\mathrm{R}^{2}$ obtained, the experimental results for simultaneous removal of Fe and Mn on NZA 200 fitted well with the Langmuir isotherm model, more so than with Freundlich isotherm model. Thus, the results indicated a monolayer adsorption of Fe and Mn on the NZA 200 surface. Similar results were reported by Vistuba et al. [38] for Mn sorption onto the commercial zeolite Controll M.F. $574^{\circledR}$.

The Dubinin-Radushkevich parameters are given in Table 4. The mean free energy value indicated a chemical process involved in simultaneous removal of Fe and Mn.

It can be concluded that the isotherm models used can be ranked in terms of suitability to describe the adsorption equilibrium of Fe and Mn onto NZA 200 in the following order: Langmuir > Dubinin-Radushkevich > Freundlich.

\subsection{Kinetic Modeling}

The kinetic studies were considered in order to obtain detailed information regarding the removal of Fe and Mn from a binary metal solution system using different quantities of NZ 200, and to determine the controlling mechanism of the adsorption process. Different kinetic models, namely pseudo-firstand pseudo-second-order, were applied to determine the reaction order and rate constants of the ion exchange.

The pseudo-first-order parameters are presented in Table 5 . The $R^{2}$ values for the pseudo-first-order calculations obtained for simultaneous removal of Fe and Mn removal on thermally activated NZ 200 at different adsorbent quantities were low. Additionally, the calculated $q_{e}$ values were different from the experimental values, indicating that pseudo-first-order kinetics could not describe the experimental data. Thus, the adsorption of Fe and Mn on NZ 200 is not a first-order reaction.

The pseudo-second-order parameters are listed in Table 5. High $R^{2}$ values were obtained via linear regression of pseudo-second-order model for Fe and Mn removal using NZ 200. As shown in Table 4, the calculated and experimental $q_{e}$ values were very close. Thus, the pseudo-second-order kinetic model was more suitable to describe the simultaneous Fe and Mn removal than the pseudo-first-order model, suggesting a chemical sorption.

João et al. [40] reported a better fit of the data by pseudo-second-order kinetic model for Fe and Mn removal in the presence of methylene blue, using zeolite synthesized from fly ash of coal. Kwakye-Awuah et al. [41] reported that pseudo-first-order model was adequate to describe the removal of Fe and Mn from groundwater by synthetic zeolite Y synthesized from bauxite and kaolin. 
Table 5. Pseudo-first-order and pseudo-second-order kinetic constants for simultaneous removal of Fe and Mn removal on thermally activated NZ 200 at different adsorbent quantities.

\begin{tabular}{cccccccc}
\hline Model & Parameters & \multicolumn{5}{c}{ Zeolite Quantity } \\
\hline & $q(g)$ & & 0.5 & 1 & 2 & 3 & 4 \\
\cline { 2 - 7 } Pseudo-first-order & $k_{1} \cdot 10^{-3}$ & $\mathrm{Fe}$ & 4.9 & 5.9 & 12.9 & 3.2 & 1.9 \\
& $(1 / \mathrm{min})$ & $\mathrm{Mn}$ & 3.4 & 4.6 & 12.1 & 4.0 & 1.6 \\
& $q_{e}($ calc $)$ & $\mathrm{Fe}$ & 5.38 & 3.64 & 1.19 & 1.23 & 1.03 \\
& $(\mathrm{mg} / \mathrm{g})$ & $\mathrm{Mn}$ & 1.35 & 1.31 & 1.23 & 1.66 & 1.95 \\
& $R^{2}$ & $\mathrm{Fe}$ & 0.8558 & 0.8689 & 0.7569 & 0.8016 & 0.9026 \\
& & $\mathrm{Mn}$ & 0.9230 & 0.9614 & 0.8211 & 0.8962 & 0.9416 \\
\hline & $q(g)$ & & 0.5 & 1 & 2 & 3 & 4 \\
Pseudo-second-order & $k_{1} \cdot 10^{-2}$ & $\mathrm{Fe}$ & 0.22 & 0.26 & 0.79 & 0.40 & 0.75 \\
& $(\mathrm{~g} / \mathrm{mg} \cdot \mathrm{min})$ & $\mathrm{Mn}$ & 0.6 & 0.2 & 7.0 & 2.0 & 2.7 \\
& $q_{e(\text { calc }}$ & $\mathrm{Fe}$ & 8.70 & 4.65 & 2.32 & 1.63 & 1.36 \\
& $(\mathrm{mg} / \mathrm{g})$ & $\mathrm{Mn}$ & 0.91 & 0.88 & 0.78 & 0.73 & 0.72 \\
& $R^{2}$ & $\mathrm{Fe}$ & 0.9985 & 0.9966 & 0.9837 & 0.9924 & 0.9263 \\
& & $\mathrm{Mn}$ & 0.9804 & 0.9871 & 0.9817 & 0.9795 & 0.9236 \\
\hline & $q_{e(\text { exp })}$ & $\mathrm{Fe}$ & 8.42 & 4.41 & 2.22 & 1.48 & 1.13 \\
& $(\mathrm{mg} / \mathrm{g})$ & $\mathrm{Mn}$ & 0.82 & 0.75 & 0.73 & 0.66 & 0.53 \\
\hline
\end{tabular}

\section{Conclusions}

In this paper, the simultaneous removal of Fe and Mn using natural zeolite thermally activated in two stages was investigated. The rough surface of thermally activated natural zeolite, having a crystal diameter between 2 and $10 \mu \mathrm{m}$, as revealed by SEM images, favors the adsorption of Fe and $\mathrm{Mn}$. Generally, Fe removal was higher than Mn removal. In the case of $\mathrm{Fe}$, the highest removal efficiency was achieved using thermally activated NZA $550(0.5-1.25 \mathrm{~mm}$ particle size) obtained in the second stage of activation (99.5\%). In the case of $\mathrm{Mn}$, higher removal efficiencies were obtained using thermally activated NZA 250 (2-3 mm particle size). The Langmuir and Freundlich parameters indicated a favorable sorption of Fe and Mn onto thermally activated NZ 200. The mean free energy (Dubinin-Radushkevich isotherm) was calculated to be $15.81 \mathrm{~kJ} / \mathrm{mol}$, which suggested that sorption of Fe and $\mathrm{Mn}$ is characterized by a chemical process. The kinetic study showed that the pseudo-second-order kinetic model was more adequate to describe the Fe and $\mathrm{Mn}$ removal from the binary metal solution system. The obtained results prove the possibility of using natural activated zeolite for simultaneous removal of $\mathrm{Fe}$ and $\mathrm{Mn}$ in the water treatment process. In line with the obtained results, the activated zeolite could be further used in a continuous fixed-bed column in order to scale up the process.

Author Contributions: C.T., I.A., and M.S. conceived and designed the experiments; E.N. and A.I.T. performed the experiments; I.A., C.T., and M.S. contributed to the activation of natural zeolite; E.N. and A.I.T. contributed to the zeolite characterization; C.T., I.A., and M.S. analyzed the data; M.S. determined the metal concentrations; E.N performed the isotherm and kinetics modeling; E.N. and A.I.T. wrote the paper. All authors read and agreed to the published version of the manuscript.

Funding: This research was funded by the Competitiveness Operational Programme of the Ministry of European Funds, contract no. 7/01.09.2016, codeMYSMIS105654, and the article processing charge (APC) was funded by the Romanian Research and Innovation Ministry under the PROINSTITUTIO project, contract no. 19PFE/17.10.2018.

Conflicts of Interest: The authors declare no conflict of interest. The funders had no role in the design of the study; in the collection, analyses, or interpretation of data; in the writing of the manuscript, or in the decision to publish the results.

\section{References}

1. Stanila, A.; Mihaiescu, T.; Socaciu, C.; Diaconeasa, Z. Removal of copper and lead ions from aqueous solution using brewer yeast as biosorbent. Rev. Chem. 2016, 67, 1276-1280. 
2. Marquez, A.; Millan, F.; Prato, J.G.; La Cruz, C. Cr(VI) ions adsorption on calcined adsorbent substrates with surface of variable charge chemically modified. Rev. Technol. Ing. Univ. Zulia. 2020, 43, 72-81.

3. Grismer, M.E.; Collison, R.S. The Zeolite-Anammox Treatment Process for Nitrogen Removal from Wastewater-A Review. Water 2017, 9, 901. [CrossRef]

4. Wasielewski, S.; Rott, E.; Minke, R.; Steinmetz, H. Evaluation of Different Clinoptilolite Zeolites as Adsorbent for Ammonium Removal from Highly Concentrated Synthetic Wastewater. Water 2018, 10, 584. [CrossRef]

5. Sulaiman, K.O.; Sajid, M.; Alhooshani, K. Application of porous membrane bag enclosed alkaline treated Y-Zeolite for removal of heavy metal ions from water. Microchem. J. 2020, 152, 104289. [CrossRef]

6. García-Mendieta, A.; Solache-Ríos, M.; Olguín, M.T. Evaluation of the sorption properties of a Mexican clinoptilolite-rich tuff for iron, manganese and iron-manganese systems. Micropor. Mesopor. Mater. 2009, 118, 489-495. [CrossRef]

7. Liu, X.; Mäki-Arvela, P.; Aho, A.; Vajglova, Z.; Gun'ko, V.M.; Heinmaa, I.; Kumar, N.; Eränen, K.; Salmi, T.; Murzin, D.Y. Zeta Potential of Beta Zeolites: Influence of Structure, Acidity, $\mathrm{pH}$, Temperature and Concentration. Molecules 2018, 23, 946. [CrossRef]

8. Cadar, O.; Hoaghia, M.A.; Kovacs, E.; Senila, M.; Miu, I. Behavior of some clinoptilolite rich natural zeolites from Romania in simulated biological fluids. In Proceedings of the 19th SGEM International Multidisciplinary Scientific GeoConference, Albena, Bulgaria, 28 June-7 July 2019. [CrossRef]

9. Senila, M.; Cadar, O.; Senila, L.; Hoaghia, A.; Miu, I. Mercury determination in natural zeolites by thermal decomposition atomic absorption spectrometry: Method validation in compliance with requirements for use as dietary supplements. Molecules 2019, 24, 4023. [CrossRef]

10. De Souza, V.C.; Villarroel-Rocha, J.; De Araújo, M.J.G.; Sapag, K.; Pergher, S.B.C. Basic Treatment in Natural Clinoptilolite for Improvement of Physicochemical Properties. Minerals 2018, 8, 595. [CrossRef]

11. Das, D.; Basak, G.; Lakshmi, V.; Das, N. Kinetics and equilibrium studies on removal of zinc (II) by untreated and anionic surfactant treated dead biomass of yeast: Batch and column mode. Biochem. Eng. J. 2012, 64, 30-47. [CrossRef]

12. Wibowo, E.; Rokhmat, M.; Abdullah, M. Why does thermal shock produce smaller particles of zeolite? Powder Technol. 2016, 301, 911-919. [CrossRef]

13. Chmielewská, E. Chapter 4-Natural zeolite: Alternative adsorbent in purification or post-treatment of waters. In Micro and Nano Technologies, Modified Clay and Zeolite Nanocomposite Materials; Mercurio, M., Sarkar, B., Langella, A., Eds.; Elsevier: Amsterdam, The Netherlands, 2019; pp. 87-112.

14. Kogel, J.E.; Trivedi, N.; Barker, J.M.; Krukowski, S.T. Industrial Minerals and Rocks- Commodities, Markets, and Users, 7th ed.; Society for Mining, Metallurgy, and Exploration: New York, NY, USA, 2006; p. 1568.

15. Duborska, E.; Urik, M.; Bujdos, M.; Matulova, M. Influence of physicochemical properties of various soil types on iodide and iodate sorption. Chemosphere 2019, 214, 168-175. [CrossRef] [PubMed]

16. Farrag, A.E.H.A.; Moghny, T.A.; Mohamed, A.M.G.; Saleem, S.S.; Fathy, M. Abu Zenima synthetic zeolite for removing iron and manganese from Assiut governorate groundwater, Egypt. Appl. Water. Sci. 2017, 7, 3087-3094. [CrossRef]

17. Vries, D.; Bertelkamp, C.; Schoonenberg Kegel, F.; Hofs, B.; Dusseldorp, J.; Bruins, J.H.; de Vet, W.; van den Akker, B. Iron and manganese removal: Recent advances in modelling treatment efficiency by rapid sand filtration. Water Res. 2017, 109, 35-45. [CrossRef]

18. Damian, G.E.; Micle, V.; Sur, I.M. Lead and copper removal from multi-metal contaminated soils through soil washing technique using humic substances as washing agents: The influence of the washing solution $\mathrm{pH}$. Stud. Univ. Babes Bolyai Chem. 2019, 64, 41-52. [CrossRef]

19. Law No. 458/2002 Quality of Drinking Water-Republished in the Official Gazette of Romania, No. 875/2011. Available online: https:/www.global-regulation.com/translation/romania/3756327/law-no.-458-of-8-july2002-\%2528republished\%2529-on-the-quality-of-drinking-water.html (accessed on 5 June 2020).

20. Adekola, F.A.; Hodonou, D.S.S.; Adegoke, H.I. Thermodynamic and kinetic studies of biosorption of iron and manganese from aqueous medium using rice husk ash. Appl. Water Sci. 2016, 6, 319-330. [CrossRef]

21. Banerjee, S.; Chattopadhyaya, M.C. Adsorption characteristics for the removal of a toxic dye, tartrazine from aqueous solutions by a low cost agricultural by-product. Arab. J. Chem. 2017, 10, S1629-S1638. [CrossRef]

22. Ekpete, O.A.; Marcus, A.C.; Osi, V. Preparation and Characterization of Acti-vated Carbon Obtained from Plantain (Musa paradisiaca) Fruit Stem. J. Chem. 2017, 2017, 8635615. [CrossRef] 
23. Langmuir, I. The constitution and fundamental properties of solids and liquids. J. Am. Chem. Soc. 1916, 38, 2221-2295. [CrossRef]

24. Kallel, F.; Chaari, F.; Bouaziz, F.; Bettaieb, F.; Ghorbel, R.; Ellouz Chaabouni, S. Sorption and desorption characteristics for the removal of a toxic dye, methylene blue from aqueous solution by a low cost agricultural by-product. J. Mol. Liq. 2016, 219, 279-288. [CrossRef]

25. Freundlich, H.M.F. Over the adsorption in solution. Z. Phys. Chem. 1906, 57, 385-470.

26. Dubinin, M.M. The Potential Theory of Adsorption of Gases and Vapors for Adsorbents with Energetically Nonuniform Surfaces. Chem. Rev. 1960, 60, 235-241. [CrossRef]

27. Deniz, F. Optimization of Biosorptive Removal of Dye from Aqueous System by Cone Shell of Calabrian Pine. Sci. World J. 2014, 2014, 138986. [CrossRef] [PubMed]

28. Deniz, F.; Karaman, S. Removal of Basic Red 46 dye from aqueous solution by pine tree leaves. Chem. Eng. J. 2011, 170, 67-74. [CrossRef]

29. Abatal, M.; Córdova Quiroz, A.V.; Olguín, M.T.; Vázquez-Olmos, A.R.; Vargas, J.; Anguebes-Franseschi, F.; Giácoman-Vallejos, G. Sorption of Pb (II) from Aqueous Solutions by Acid-Modified Clinoptilolite-Rich Tuffs with Different Si/Al Ratios. Appl. Sci. 2019, 9, 2415. [CrossRef]

30. Ho, Y.S.; McKay, G. The Kinetics of Sorption of Divalent Metal Ions onto Sphagnum Moss Peat. Water Res. 2000, 34, 735-742. [CrossRef]

31. Bish, D.; Boak, J. Clinoptilolite-heulandite nomenclature. Rev. Mineral. Geochem. 2001, 45, 207-216. [CrossRef]

32. Jmayai, A.; Hermassi, M.; Alouani, R.; Cortina, J.L.; Hadj Amara, A.B. Characterization of natural Yemeni zeolites as powder sorbents for ammonium valorization from domestic waste water streams using high rate activated sludge processes. J. Chem. Technol. Biotechnol. 2018, 93, 1748-1756. [CrossRef]

33. Hałas, P.; Kołodyńska, D.; Płaza, A.; Géca, M.; Hubicki, Z. Modified fly ash and zeolitesas an effective adsorbent for metal ions from aqueous solution. Adsorpt. Sci. Technol. 2017, 35, 519-533. [CrossRef]

34. Inglezakis, V.J.; Doula, M.K.; Aggelatou, V.; Zorpas, A.A. Removal of iron and manganese from underground water by use of natural minerals in batch mode treat-ment. Desalin. Water Treat. 2010, 18, 341-346. [CrossRef]

35. Baker, H.M.; Massadeh, A.M.; Younes, H.A. Natural Jordanian zeolite: Removal of heavy metal ions from water samples using column and batch methods. Environ. Monit. Assess. 2009, 157, 319-330. [CrossRef] [PubMed]

36. Moazeni, M.; Parastar, S.; · Mahdavi, M.; Ebrahimi, A. Evaluation efficiency of Iranian natural zeolites and synthetic resin to removal of lead ions from aqueous solutions. Appl. Water Sci. 2020, 10, 60. [CrossRef]

37. Waqas, M.; Nizami, A.S.; Aburiazaiza, A.S.; Barakat, M.A.; Asam, Z.Z.; Khattak, B.; Rashid, M.I. Untapped potential of zeolites in optimization of food waste composting. J. Environ. Manag. 2019, 241, 99-112. [CrossRef]

38. Vistuba, J.P.; Coral, L.A.; Pizzolatti, B.S.; Vitali, L.; Nagel-Hassemer, M.E.; Lapolli, F.R.; Lobo-Recio, M.Á. Adsorption behaviour of the zeolite, Controll M.F. $574^{\circledR}$ in removing iron and manganese from natural water. Desalin. Water Treat. 2015, 55, 1523-1533. [CrossRef]

39. Yousef, R.I.; El-Eswed, B.; Al-Muhtaseb, A.H. Adsorption characteristics of natural zeolites as solid adsorbents for phenol removal from aqueous solutions: Kinetics, mechanism, and thermodynamics studies. Chem. Eng. J. 2011, 171, 1143-1149. [CrossRef]

40. João, J.J.; Satiro Júnior, W.; Vieira, J.L. Use of zeolite synthesized from coal ashl from Santa Catarina for removal of iron, manganese and methylene blue dye in water. Rev. Ambiente Água 2018, 13, e2224. [CrossRef]

41. Kwakye-Awuah, B.; Sefa-Ntiri, B.; Von-Kiti, E.; Nkrumah, I.; Williams, C. Adsorptive Removal of Iron and Manganese from Groundwater Samples in Ghana by Zeolite Y Synthe-sized from Bauxite and Kaolin. Water 2019, 11, 1912. [CrossRef]

(C) 2020 by the authors. Licensee MDPI, Basel, Switzerland. This article is an open access article distributed under the terms and conditions of the Creative Commons Attribution (CC BY) license (http://creativecommons.org/licenses/by/4.0/). 